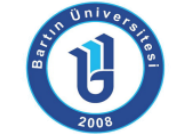

ISSN: 1308-7177

\title{
Türkçenin Yabancı Dil Olarak Öğretiminde Kullanılan Ders Kitaplarında Metinler Arası Aşamalılık: Yedi İklim Türkçe ve İzmir Üzerine Karşılaştırmalı Bir İnceleme
}

Mehmet KARA, Doç. Dr., Gazi Üniversitesi Eğitim Fakültesi, mehkara@gazi.edu.tr

Yunus Emre ÇEKICi, Okutman, Adana Bilim ve Teknoloji Üniversitesi Türk Dili Bölümü, yecekici@adanabtu.edu.tr

Öz: Yabancı dil olarak Türkçe öğretimi, metin alımlamaya ve metin üretmeye dayanır. Bu nedenle yabancı dil olarak Türkçe öğretimi alanında metindilbilimsel incelemeler yapmak bir zorunluluktur. Bu bağlamda metinsellik ölçütlerinden metinler arasılık, önemli bir inceleme konusudur. Bu araştırmanın amacı, Yunus Emre Enstitüsünün hazırladığı Türkçenin yabancı dil olarak öğretiminde kullanılan Yedi İklim Türkçe ile Dokuz Eylül Üniversitesi DEDAM'ın hazırladığı İzmir ders kitaplarında yer alan metinlerin, metinler arası aşamalıığını betimlemeye çalışmaktır. Bu amaçla A1 ve A2 düzeyindeki ders kitapları, karşılaştırmalı olarak incelenmiştir. Betimsel bir nitelik taşıyan bu çalışmada doküman analizi yöntemi kullanılmıştır. Metinler arası aşamalılık konu, karakter ve fotoğraf aşamalılığı olmak üzere üç alt başlıkta karşılaştırmalı olarak değerlendirilmiştir. Genel olarak Yedi İklim Türkçe'nin İzmir'e göre metinler arası aşamalılığa daha uygun olarak oluşturulduğu tespit edilmiştir.

Anahtar Kelimeler: yabancı dil olarak Türkçe öğretimi, ders kitabı, metinler arasılık, aşamalılık

\section{Intertextual Progressivity in Textbooks Used in Teaching Turkish As A Foreign Language: A Comparative Study on Yedi İklim Türkçe and İzmir}

\begin{abstract}
Teaching Turkish as a foreign language is based on text reception and text production. Teherefore, it is a necessity to do text linguistic studies in the field of teaching Turkish as a foreign language. In this context, intertextuality, one of the criteria of textuality is an ipmortant research topic. The aim of this research is to try to describe the progressivity of the intertextuality of texts in Yedi iklim Türkçe (Yunus Emre Institue) and İzmir (Dokuz Eylül University DEDAM) textbooks. For this purpose, textbooks at the $\mathrm{A} 1$ and $\mathrm{A} 2$ level have been examined comparatively. In this study which has a descriptive nature, document analysis method is used. Intertextual progressivity have been evaluated comparatively in three sub-sections: topic, character and photo progression. In the research, it was determined that Yedi İklim Türkçe is more appropriately organized in terms of intertextuality progressivity according to İzmir
\end{abstract}

Key Words: Teaching Turkish as a foreign language, textbook, intertextuality, progressivity 


\section{GiRiş}

Gerek ana dili gerekse yabancı dil eğitiminin son yıllarda metin odaklı gerçekleştirilmesi, metin dilbilim ile dil öğretimi arasındaki disiplinler arası işbirliğini hem gerekli hem de kaçınılmaz kılmaktadır. Türkçenin yabancı dil olarak öğretiminde özellikle iletişim ve eylem odaklı yaklaşımın ağılık kazanmasıyla, dilin kurallarından çok kullanımına ağırlık verilmekte ve bu gelişme metin odaklı dil öğretimine zemin hazırlamaktadır. Bu nedenle de Türkçenin yabancı dil olarak öğretimi alanında metin dilbilimsel araştırmalara duyulan gereksinim her geçen gün artmaktadır. Aynı zamanda yabancı dil olarak Türkçe öğretiminde farklı metinlerden oluşan ders kitaplarının sıklıkla kullanılması da yine bu alanda metin dilbilimsel incelemeleri gerekli kılan bir diğer etkendir.

Metin dilbilim, bir metnin yapısını, düzenlenişini ve işleyişini incelerken tümceler arasındaki göndermeleri, bağlantı ögelerini, dil içi ve dil dışı bağıntıları ele alır (Korkut 2015, s. 159). Metin dilbilim; metin türleri arasındaki ilişkileri araştıran, metinlerin anlamsak yapılarını, kullanım alanlarını, iletişimsel işlevlerini saptamaya çalışan dilbilimin alt alanlarından biridir (Demir, 2006, s. 16). Metin dilbilimin amacl, metin üretimine ilişkin genel kural ve koşulları dizgeli olarak betimlemek ve bunların metin alımlamadaki önemini açıklamaktır (Kanatlı, 1998, s. 36). Metin dilbilim, metnin yüzey ve derin yapıdaki kurgulanış biçimlerini ve bildirişimsel işlevlerini ortaya çıkarmayı, böylece metin oluşturmanın genel koşul ve kurallarını belirlemeyi amaçlar. Bir başka deyişle metin dilbilim, metni metin yapan ölçütleri saptamaya çalışır (Şenöz Ayata, 2005, s. 22-23). Türkçe öğretimi de temelde metin alımlamaya ve metin üretmeye dayandığı için, metin dilbilim ile Türkçe öğretimi arasındaki işbirliği kaçınılmazdır. Alan yazını incelendiğinde bu işbirliği içindeki çalışmaların genelde metinsellik, özelde de bağdaşıklık ve tutarlılık ölçütleri üzerinde yoğunlaştığı görülmektedir (Bkz. Biçer ve Çoban, 2015; Can, 2014; Çocuk ve Kanatlı, 2012; Karadeniz, 2015; Karatay, 2010a; Kartal ve Bozkurt, 2014; Seçkin, Arslan ve Ergenç, 2014; Taşıgüzel, 2004; Ülper, 2011).

Iletişimde metinlerin işlevini inceleyen De Beaugrande ve Dressler (1981'den aktaran Coşkun Ögeyik, 2008) bir dilsel ürünü metin yapan ölçütleri yedi başlıkta toplamıştır: bağdaşıklık, tutarlılık, amaçılıık, kabul edilebilirlik, bilgilendiricilik, durumsalık ve metinler arasılık. Görüldüğü gibi bağdaşıklık ve tutarlılık, metinsellik ölçütlerinden yalnızca iki tanesini oluşturmaktadır. Dolayısıyla diğer metinsellik ölçütleri de Türkçe eğitimi açısından ele alınmalı, gerek öğrencilerin yazdığı gerek öğrencilere yönelik yazılan gerek de ders kitabındaki metinler diğer metinsellik ölçütlerine göre de irdelenmelidir. Bu bağlamda, bir metnin, başka başka metinlerin özgün toplamından ibaret olduğu görüşünü ifade eden metinler arasılık ölçütü de yabancı dil olarak Türkçe öğretimi bağlamında incelenmesi gereken bir değişkendir.

Birçok dilbilimciye göre metinler arasılık, metinsellik ölçütleri arasında önemli bir yer tutar. Türkçe eğitiminde hem öğrencilerin yazılı ve sözlü metinlerini incelerken hem onların metin oluşturma süreçlerine katkı sağlarken hem de ders kitaplarına metin seçerken, metinler arasılık ölçütünden yararlanılması bir gerekliliktir. Alan yazını incelendiğinde Türkçe eğitimi bağlamında metinler arasılığı konulaştıran kimi çalışmalara rastlanmaktadır. Karatay (2010b) Türkçe ders kitaplarındaki metinler arası ilişkilerin yapılandırmacı yaklaşıma uygun olarak öğrenciyi etkin kılacağını savunur. Bir başka araştırmada ortaokul Türkçe ders kitaplarında yer alan okuma kültürü temalı metinler, metinler arasılık bağlamında incelenmiştir (Çeçen ve Doğan, 2014). Benzer bir çalışmada MEB tarafından basılan 7. sınıf Türkçe ders kitaplarında yer alan metinler, metinler arası ilişkiler bağlamında değerlendirilmiştir (Demir, 2009). Bir diğer çalışmada Türkçe öğretmeni adaylarının yetizleme çalışmaları çerçevesinde oluşturdukları yazılı metinler, metinler arasılık ölçütüne göre ele alınmıştır (Göçer, 2012). Genelde ana dili 
eğitimi üzerinde yoğunlaşan bu çalışmaların yanı sıra, yabancı dil olarak Türkçe öğretiminde de metinler arasılık, bir inceleme konusu olabilir. Bu noktada çalışmanın amacına geçmeden önce metinler arasılık kavramını derinleştirmek yararlı olabilir.

\subsection{Metinler Arasılık}

Günümüzde, edebiyattan halk bilimine, dilbilimden medya araştırmalarına varıncaya kadar birçok farklı disiplinin inceleme konusu ve yöntemi olan metinler arasılık, disiplinler arası bir kavramdır. Böylesine geniş bir alanda ele alınan metinler arasılığın tarihi, kavramın adlandırımasının tarihinden elbette daha eskidir. Başka bir deyişle, ilkesel olarak ilk metinden bugüne, üretilen bütün metinler başka metinlerin izlerini taşır ve her metin doğası gereği metinler arasıdır. Metinler arasılığın tarihi, ilk metnin üretimiyle başlar fakat bu olgunun adlandırıması, varlığına göre yenidir. Bu noktada metinler arasılığı ilk kavramsallaştıran kişi olarak Julia Kristeva'nın adını anmak bir zorunluluktur. "Metinler arasılık bir terim olarak ilk kez 'Word, Dialogue and Novel' (1966) ve sonra 'The Bounded Text' (1966-1967) adlı makalelerde Julia Kristeva tarafından kullanılmıştır" (Alforo, 1996, s. 28). Kristeva'ya göre (1969, s. 85) her metin bir alıntılar mozaiğidir, her metin kendi içinde başka bir metnin eritilmesi ve dönüşümüdür (Akt. Aktulum, 2014, s. 35). Kristeva'nın Rus eleştirmen Mihail Baktin'in "söyleşim" terimine dayanarak oluşturduğu metinler arasılık (Aktulum, 2014, s. 34), öncelikle edebiyat dünyasında etkisini göstermiştir. Metinler arasılık, özellikle postmodern edebiyat için özgün bir ipucu niteliği taşır. Bununla beraber, metinler arasılı̆̆ın salt edebi metinlere özgü olmadığı, genel bir metinsellik ölçütü olduğu savından hareketle dilbilimsel incelemeler de ağırlık kazanmıştır.

Önceden metinler çoğunlukla çağının toplumsal özelliklerine, yazarın yaşamına ve psikolojisine, beklentilerine, ilgilerine göre ele alınıyordu; fakat daha sonra söylemlerin iç iç içe geçerek çok sesli olduğu, metinlerin üst üste gelerek birbirine harmanlandığı, metnin ve anlamın büyük ölçüde önceki metinlerden gelen kesitlerin iç içe geçmelerine, birbirine karışmalarına bağlı olarak üretildiği savı ileri sürülerek yeni bir metin tanımı ve anlayışı ortaya kondu (Aktulum, 2014, s. 9). Bu bağlamda metinler arasılık hem metin üretiminde hem de metnin alımlanmasında ve yorumlanmasında, metni metin yapan bir ilke olarak değerlendirilmeye başlandı.

1960'lı yılların sonunda gelişmeye başlayan metin dilbilim alanında (Çocuk ve Kanatlı, 2012 , s. 67) önceki metinlerle gelecekte üretilecek metinler arasında dolaysız bir etkileşim olduğu görüşü ortaya atıldı. Bu görüşe göre "Her metinsel üretim, önceki metinleri varsayar ve gelecekte üretilecek metinlere beklenti oluşturur" (Bauman, 2008, s. 116). Bu diyalektik ilişkiden beslenen metinler arasılık "en basit biçimiyle farklı metinlerin yan yanalığı, iç içeliği biçiminde tanımlanabilir" (Bloome ve Egan-Robertson, 1993, s. 305). Başka bir tanıma göre bir metnin bir başka, öncel metinle olan ilişkisi, bağıntısı, hatta başka metinlerin dönüşüme uğramasıdır (Ekiz, 2007, s. 124). Metin arkeolojisi olarak da adlandırılan metinler arasılık (Sakallı, 2014, s. 156), bir metnin eski metinlerden aldıkları, bu sonraki metnin önceki metinlerle ilişki ve ilişkilendirilme biçimidir (Karaağaç, 2013, s. 590).

Yukarıda anılan tanımlardan hareketle şunları söylemek olanaklıdır: Metinler arasılık, birbirini sonsuzlayan berber aynaları gibi veya her kapısı başka bir odaya açılan sonsuz odalı bir ev gibidir. Her metin başka bir metne açılır, her metinde başka bir metnin izi sürülür ve bu yolculuk bitimsizdir. Okuyucu metni kazıdıkça, metnin anlam ayrıntılarını keşfetmeye çalıştıkça başka metinlerin kalıntılarıyla karşılaşır ve eğer isterse metnin içindeki diğer metinlerin peşine düşer. Metnin içindeki o diğer metinler de doğal olarak başka metinlere ev sahipliği yapmıştır. Dolayısıyla metinler arasılık, birbirini içeren metin zincirini ziyaret etmek, bitimsiz bir yolculuğa çıkmak, sonu gelmeyen anlam ayrıntılarını kovalamak demektir. Diğer bir ifadeyle metinler 
arasılık, başka metinlerin işbirliği, paylaşımı, etkileşimi, geçirgenliği, bir metnin diğerini misafir etmesi olarak tanımlanabilir. Metinler arası bir metni okumak, başka metinlerin peşine düşmek, sürekli yolda olmak, belki de kaybolmayı göze almaktır. Bu açıdan bakıldığında metinler arasılık noktasal değil süreçsel, çizgisel değil zikzaklıdır, bu nedenle de hem yazarın hem de okurun bu zikzaklı yolda anlam inşa etme eylemidir.

Günay'ın (2007, s. 211) aşağıdaki ifadeleri, metinler arasılığın içeriğini özetlemektedir:

\begin{abstract}
Bir metin diğer tüm anlatımlardan yalıtılmış, onlardan soyutlanmış bir şey değildir. Bir metin tek başına yazılmamıştır, tek başına değildir ve tek başına okunamaz. Bu metnin başka metinlerle ilişkisine göre bir değeri ve anlamı vardır. Metinler arası kavramı; kültürel ortam, alıntılar, şu ya da bu biçimde gönderimde bulunulan metinler ve metin türleri ile ilgili bir kavramdır. Metinler arasılık kavramı, bir metin ya da metinler grubunun başka metinlerle olan açık ya da gizli ilişkilerini belirtir. Her metin, geniş bir bağlam göz önünde tutularak yazılır, yine her metin, kendisinden önce yazılmış ve biçem, izlek ya da bir başka açıdan az ya da çok etkilenmiş olup bu metinlerle doğrudan ya da dolaylı olarak etkileşim içindedir.
\end{abstract}

Yukarıdaki tanım ve görüşlerden anlaşıldığı gibi metinler arasılık salt yazarın bir metin üretme yöntemi değil, bunun ötesinde okurun metni anlama ve anlamlandırma izlemidir. Still ve Worton'a göre $(1990$, s. 2) metinler arasılık kuramı, bir metnin kendi başına yeterli ve geçirişimsiz olamayacağını, bu yüzden kapalı bir dizge olarak işlev göremeyeceğini savunur. Bunun iki nedeni vardır: i) Yazar bir metni yaratmadan önce aynı zamanda bir okuyucudur, bu yüzden metin kaçınılmaz olarak diğer metinlere göndermeleri, diğer metinlerden etkilenmeleri içerir. ii) Bir metin sadece kimi okuma süreçleri sayesinde varlık kazanır, metin farklı metinlerin ilişkilendirilerek okunmasıyla üretilir. Ekiz'e göre (2007, s. 124) metinlerin öncel metinlerle kurduğu etkileşim, okuru ön plana çıkaran, onu etkin kılan, anlam üretmeye zorlayan bir ilişki türüdür. Allen da $(2005$, s. 1) benzer bir görüşü dile getirir: "Bir metni yorumlamak, onun anlamını veya anlamlarını keşfetmek metinler arası ilişkilerin izini sürmektir. Böylece okuma, metinler arasında bir yolculuğa çıkma süreci olur. Anlam, bir metin ile onun gönderimde bulunduğu ve ilişkide olduğu diğer metinler arasında var olur. Metin, metinler arası olur." Karatay da (2010b), metinler arasılığı okuma ve anlam oluşturma sürecinde okurun zihninde başka metinleri canlandırması olarak tanımlar. Bir başka görüşe göre öğretmenler ve öğrenciler metinler arasılığı bilgi kaynağı olarak önceki olayları tanımak ve doğrulamak amacıyla kullanır ve sosyal bir biçimde inşa eder (Bloome ve Egan-Robertson, 1993, s. 304). Eziler Kıran ve Kıran'a göre (2011, s. 359), okumak bir metni başka bir metinle ilişkilendirmek, onda yeni bir tat bulmak, o metnin ilginç bir yanını yakalamaktır. Bir okuma tekniği olarak metinler arasılık okurun farklı metinlerin izini sürmesi, farklı metinlerle iletişime geçmesi, bu etkileşimden tat almasıdır. Metinler arasında okumak, farklı metinlerin etkileşimi ve çekişmesine tanıkıı etmek, bu yolla anlamı inşa etmektir. Metinler arasılık ölçütüne göre okur, metinin edilgen bir alıcısı değil, metnin anlam ortağıdır. Bu bakımdan ders kitaplarındaki metinlerde metinler arası ilişkilerin varlığı, okurun çözümleme, ilişkilendirme, gerekçelendirme ve birleştirme becerisine katkı sunabilir.

Yabancı dil olarak Türkçe öğretimi alanında kullanılan ders kitaplarında yer alan metinlerin metinler arası yapısı, öğrencilerin ön organize edicileri kullanmasını ve öğrendiklerini düzenlemelerini ve yapılandırmalarını sağlayabilir. "Ön organize ediciler, yeni bilgiler için bir yapı oluşturan, yeni bilginin çerçevesini çizen ve öğrencinin daha önce kazanmış olduğu bilgi ile ilişkilendirilmesini sağlayan başlangıç, hazırlık çalışmalarıdır" (Karatay, 2013, s. 244). Ders kitaplarındaki metinlerin metinler arası aşamalılı̆̆, öğrenci için ön organize edici işlev taşımaktadır. Öğrenci, her yeni metinde, önceki metnin izini sürerse öğrenmede devamlılık ve aşamalılık sağlanabilir. Bunun sağlanabilmesi için de konu, karakter ve 
fotoğrafların metinler arası aşamalılık ilkesine göre oluşturulması gerekmektedir. Kısacası metinler arasılık, bir yazma ve okuma tekniği olmasının ötesinde, derslerde anlam inşa etme ve bilgiyi yapılandırma süreçlerine olumlu katkısı olan bir metinsellik ölçütüdür. Bu noktada, yabancı dil olarak Türkçe öğretimi alanındaki ders kitaplarının metinler arası aşamalıık bağlamında incelenmesi gerekliliği ortaya çıkmaktadır.

\section{2. Araştırmanın Amacı}

Bu araştırmanın amacı, Yunus Emre Enstitüsünün hazırladığı Türkçenin yabancı dil olarak öğretiminde kullanılan "Yedi İklim Türkçe" ile Dokuz Eylül Üniversitesi Dil Eğitimi Uygulama ve Araştırma Merkezinin (DEDAM) hazırladığı "izmir" ders kitaplarında yer alan metinlerin, metinler arası aşamalıı̆̆ını betimlemeye çalışmaktır. Bu amaçla A1 ve A2 düzeyindeki ders kitapları, karşılaştırmalı olarak incelenmiştir.

Her metin doğası gereği metinler arasıdır; fakat ders kitaplarında yer alan metinler, rastgele düzenlenmekten çok çok dizgeli bir metinler arası aşamalılık ile örgülenmelidir. Metinlerde yeni bilgi, düşünce veya duygu; öncel metinlerin üzerine inşa edilmeli; metinler arası aşamalııı, ders kitaplarındaki metinlerin, bir merdivenin basamakları gibi birbirini içermesi ve aşması şeklinde olmalıdır. Türkçe ders kitapları, farklı metinlerin gelişigüzel sıralandığı bir metin deposu değildir; tersine bu kitaplardaki metinler birbirini takip etmeli, birbirini içermeli ve her yeni metinde birbirini aşmalı; her yeni metin, bir öncekine bağlı olarak gitgide yükselmelidir. Böylesi metinler, öğrenmede ön organize edicileri harekete geçirerek çözümleme, ilişkilendirme, gerekçelendirme ve birleştirme gibi bilişsel becerilere katkı sağlayabilir. Aynı zamanda öğretimdeki yakından uzağa, somuttan soyuta ilkeleri de yine metinler arası aşamalılığı gerektirmektedir. Metinler arası aşamalııı, ön bilgilerle yeni bilgilerin organize edilmesini sağlayabilir.

Çalışmada, Yedi İklim Türkçe ile İzmir ders kitaplarındaki metinler arası aşamalılık, üç farklı başık altında karşılaştırmalı olarak incelenmiştir:

1. Metinler Arası Konu Aşamalılığı

2. Metinler Arası Karakter Aşamalıı̆ı̆

3. Metinler Arası Fotoğraf Aşamalılığı

\section{YÖNTEM}

\subsection{Araştırmanın Modeli}

Betimsel nitelikte olan bu çalışmada, doküman analizi yöntemi kullanılmıştır. Doküman analizi, araştııılması hedeflenen olgu veya olaylar hakkında bilgi içeren yazılı materyallerin analizi biçiminde tanımlanmaktadır (Yıldırım ve şimşek, 2008, s.187). Bu çalışmada ders kitaplarındaki metinleri betimlemek ve karşılaştırmak amaçlandığı için, doküman analizi yönteminin, çalışmanın amacına uygun olduğu düşünülmektedir.

\subsection{Evren ve Örneklem}

Yunus Emre Enstitüsü tarafından yayımlanan Yedi İklim Türkçe ile Dokuz Eylül Üniversitesi DEDAM tarafından hazırlanan İzmir ders kitapları, çalışmanın evrenini oluşturmaktadır. Örneklem olarak ise her iki kurumun A1 ve A2 düzeyindeki ders kitapları seçilmiştir. Son zamanlarda üniversitelere bağlı TÖMER'lerde genelde Yunus Emre Enstitüsünün, Geçici Eğitim Merkezlerinde de Dokuz Eylül Üniversitesi DEDAM'ın kitaplarının okutulduğu gözlemlenmektedir. Uygulamada sıkça kullanıldığı için, bu iki kitabın incelenmesine karar verilmiştir.

Yedi İklim Türkçe 2015 yııında, Türkiye Diyanet Vakfı Matbaasında basıımıştır. Yrd. Doç. Dr. Erol Barın, Dr. Şaban Çobanoğlu, Prof. Dr. Şeref Ateş, Doç. Dr. Mustafa Balcı, Doç. Dr. Cihan 
Özdemir kitabın editörleri; Yrd. Doç. Dr. İbrahim Gültekin, Doç. Dr. Mahir Kalfa, Yrd. Doç. Dr. Filiz Mete, Aydan Eryiğit, Uğur Kılıç kitabın yazarlarıdır. Yedi İklim Türkçe'nin görsel yayın yönetmeni Zeynep Sevde Paksu, Görsel Yayın Danışmanı Dr. Melike Günyüz'dür. A1 kitabı 191, A2 kitabı 187 sayfadan oluşmaktadır.

İzmir Yabancılar İçin Türkçe Ders Kitabı 2012 yılında Papatya Yayınevi tarafından İstanbul'da basılmıştır. Kitabı yayına hazırlayanlar: Prof. Dr. V. Doğan Günay, Yrd. Doç. Dr. Özden Fidan, Okt. Uzm. Betül Çetin ve Okt. Dr. Funda Yıldız'dır. İzmir'in görselleri Duygu Fidan tarafından hazırlanmıştır. A1 ve A2 kitabı yüzer sayfadan oluşmaktadır.

\subsection{Verilerin Toplanması ve Çözümlenmesi}

Ders kitaplarındaki metinler arası aşamalılık belirlenirken yarı yapılandırılmış gözlem formu kullanılmıştır. Yedi İklim Türkçe ile İzmir, bu form aracılığıyla ayrı ayrı incelenerek daha sonra karşılaştırımıştır. Yarı yapılandırılmış gözlem formunda i) metinler arası konu aşamalıı̆̆ı, ii) metinler arası karakter aşamalıı̆̆ı ii) metinler arası fotoğraf aşamalıı̆̆ı başıkları bulunmaktadır. Belirlenen metinler arası aşamalılık örneklerinden sadece karakteristik özellik taşıyanlar; bulgular başığı altında açıklanmış, örneklendirilmiş, karşılaştırılmış ve yorumlanmıştır.

\section{BULGULAR VE YORUM}

Bu başık altında incelenen farklı kitaplardaki konu, karakter ve fotoğraf aşamalıılı̆ına ilişkin metinler arası ilişkiler açıklanmış, örneklendirilmiş, karşılaştırılmış ve yorumlanmıştır.

\subsection{Yedi İklim Türkçe'de Metinler Arası Konu Aşamalılığına iliş̧in Bulgular ve Yorum}

Yunus Emre Enstitüsünün Türkçe Öğretim Setindeki ders kitaplarında, hem A1 hem de A2 düzeyindeki metinlerin konuları, ünitelere dayalı olarak yapılandııımıştır. Başka bir deyişle, Yedi İklim Türkçe'deki metinler, ünite temellidir. Her iki kitapta da sekizer ünite bulunmaktadır. A1 kitabının üniteleri sırasıyla şöyledir: Tanışma, Ailemiz, Günlük Hayat, Çevremiz, Meslekler, Ulaşım, Iletişim, Tatil. A2 kitabının üniteleri ise yine sırasıyla şöyledir: Zaman Mekân, Sağlıkı Yaşam, Sosyal Etkinlikler, Güzel Ülkem, Üretimden Tüketime, Duygular, Teknoloji ve iletişim, insan ve Toplum. Üniteler arasındaki konu aşamalılı̆ı incelendiğinde A1 kitabının basamak basamak genişlediği, yakından uzağa ilerlediği söylenebilir. Önce tanışmanın, sonra ailenin, daha sonra da günlük hayat ve çevrenin verilmesi; çevrenin ardından meslekler, ulaşım, iletişim ve tatilin konu olarak seçilmesi bir önceki konuyu hesaba katan ve bir sonraki konuya zemin hazırlayan bir aşama izlemektedir. Fakat A2 kitabının üniteler arasındaki konu aşamalıı̆ğı belirli bir sıradüzen izlememektedir. Konular birbiriyle ilişkilendirilmeden, temalar arasında bağımsız bir yapı olarak oluşturulmuştur. Temalar arası konu aşamalılığı bakımından A1 kitabının A2 kitabına göre ilişkilendirme, birleştirme ve çözümlemeye daha elverişli olduğu söylenebilir.

Ünite içindeki metinler arası konu aşamalılığına bakıldığında, her iki kitabın da genel olarak tutarlı olduğunu söylemek olanaklıdır. Sözgelimi A1 kitabının "Çevremiz" adlı dördüncü ünitesindeki "Bizim Sokağımı"” başlıklı dinleme metninde Mustafa Bey kendi sokağını tanıtmaktadır. Aynı ünitede "Arkadaşım Derya" başlıklı diyalogda Derya'nın evi ve çevresine ilişkin konuşmalar geçmektedir. Aynı ünitedeki "Üniversitem", "Kızılay Meydanı", "Muhtarlık Nerede?" gibi metinler de kişinin sosyal çevresini tanıtan konular etrafında kurgulanmıştır. Aynı zamanda "çevre" konulu bu metinlerden yola çıkarak çeşitli dilbilgisi yapıları da öğrencilere aktarılmıştır. Bütün ünitelerde, dilbilgisi yapıları bağımsız birer konu olarak değil, metne dayalı olarak işlenmiştir. Dilbilgisi yapılarının metne dayalı olarak verilmesi de bir metinler arasılık ilişkisi olarak değerlendirilebilir. Yine A2 kitabının da ünite içi metinler arası konu aşamalılığı bakımından tutarlı olduğu düşünülmektedir. Söz konusu kitabın "Sağlıklı Yaşam" başlıkı ikinci ünitesi, bu yargıya örnek gösterilebilir. İkinci ünitedeki "Bahar Hastalıklarına Dikkat", "Kırmızı 
Burun", "Alerjik Nezle”, "Nane Limon Kabuğu”, "ihtiyarlıktandır", "Uzaylılar Kızamık Yapıyor", "Üsküdar'da Zincirleme Trafik Kazası" ve "Trafik Psikolojisi" başııkı metinler sağlıklı yaşam konusuna uygundur. Söz konusu metinler arasında önce hastalık konusu ele alınmakta, sonra trafik kazalarına geçilmektedir ki bu geçiş, birbiriyle ilişkilendirilebilir. Bu bakımdan incelenen kitapların genel olarak ünite içi metinler arası konu aşamalılığı gözetilerek hazırlandığı, yakından uzağa bir sıradüzen izlediği; fakat üniteler arası konu aşamalılığında A2 kitabının A1 kadar ilişkisel konulara yer vermediği söylenebilir.

\section{2. İzmir'de Metinler Arası Konu Aşamalıı̆ı̆ına İlişkin Bulgular ve Yorum}

Yedi İklim Türkçe'ye koşut olarak İzmir'deki metinlerin de ünite temelli olduğu söylenebilir. İzmir'in her iki kitabında da sekizer ünite yer almaktadır. A1 kitabının üniteleri sırasıyla şöyledir: Merhaba, Nerede Ne Yapıyorsun?, Biz Öğrenciyiz, Nereden Nereye?, Geçmişte, Ailem ve Arkadaşlarım, Ne Yapalım?, Tekrar Ediyoruz. A2 kitabının üniteleri ise yine sırasıyla şöyledir: Alışveriş, Geziyoruz, Doktora Gidiyorum, Gelecekte, Davranışlar, Kim 'Ne' Dedi?, Kimmiş Neymiş Nasılmış?, Tekrar Ediyoruz. İzmir'in Yedi İklim Türkçe'ye göre Üniteler arası konu aşamalılı̆ı bakımından daha az bağlantılı olduğu vurgulanabilir. Yedi iklim Türkçe'nin A1 kitabında üniteler arasında bir sıradüzen ilişkisi varken İzmir'in hem A1 hem de A2 kitabında ünitelerin birbiriyle bağlantısı daha zayıftır. Bu durum, bir üniteden diğerine geçerken kopukluğa ve dağınıklığa yol açabilir.

Ünite içindeki metinler arası konu aşamalılığına bakıldığında, İzmir'in A1 kitabında kimi konu dışı metinlere rastlamak olanaklıdır. Sözgelimi, İzmir A1 kitabının "Biz Öğrenciyiz" başlıkıı üçüncü ünitesinde önce İzmir Hayvanat Bahçesi'ni tanıtan, sonra kurstaki ilginç bir sınıftan söz eden, daha sonra İtalyan bir polisin kendinden bahsettiği üç farklı metin yer almaktadır. Görüldüğü gibi, metinlerden sadece birisi "öğrencilik" konusuna uygundur. Söz konusu ünitedeki üç metin, üç farklı konuyu ele almaktadır ve konular arasında aşamalı bir geçiş ilişkisi söz konusu değildir. İzmir A2 kitabı, ünite içindeki metinler arası konu aşamalılı̆ı bakımından incelendiğinde ise $A 2$ 'nin $A 1$ 'e göre daha tutarlı bir aşamalılık izlediği söylenebilir. Sözgelimi İzmir A2 kitabının üçüncü ünitesi olan "Doktora Gidiyoruz" başlıklı ünitede yer alan okuma metinlerinin tamamı sağlık konusuyla ilişkilidir. Bu bakımdan metinler arası geçişi sağlamak hem öğretmen hem de öğrenci için görece daha kolaydır.

\subsection{Yedi İklim Türkçe'de Metinler Arası Karakter Aşamalııı̆ığına iliş̧in Bulgular ve} Yorum

A1 ve A2 düzeyindeki metinler, Türkçe öğrenenlerin günlük somut yaşam gereksinimlerini karşılamaya dönük olduğundan, genelde diyalog türündedir. Diyaloglar karakterlerin karşılıkı konuşmasına dayalı bir metin türü olarak tanımlanır. Incelenen ders kitaplarında, diyaloglardaki karakterler, farklı zaman ve mekânlarda birbirleriyle iletişime geçmekte, günlük yaşamla ilgili çeşitli konuları birbirleriyle paylaşmaktadır. Böylece Türkçe öğrenenler, çeşitli iletişim ortamlarına ve dilsel bağlamlara tanık olmaktadır. Derya, Murat, Ömer, Deniz, Ahmet, Yaren, Meryem, Zeynep, Mustafa, irfan, Filiz, Emine, Kemal, Sedat, Asuman, Esra, Hatice, Emin... adlarındaki karakterler akrabalık ya da arkadaşlık bağı ile birbirine bağlı olduğundan, diyaloglar farklı zaman ve mekânlardaki iletişimsel süreçleri yansıtabilir niteliktedir.

Incelenen kitaplardaki karşılıklı konuşma metinlerinde genellikle bir başkarakter yer almakta, olayı başkarakterin ifadeleri sürüklemektedir. Merkezdeki başkarakter, farklı metinlerde değişebilmektedir. Yani iletişim bağlamına göre kitaplardaki farklı karakterler başkarakter olabilmektedir. Sözgelimi bir metinde İrfan Bey merkezdeyken, diğer metinde İrfan Bey yer almasına rağmen Filiz Hanım başkarakter rolünü üstelenebilmektedir. Kitaplardaki karakterler, yaş aralığı, cinsiyet, meslek, öğrenim durumu gibi açılardan farklılıklar 
sergilemektedir. Bu nedenle çeşitli iletişim durumlarını yansıtan diyalog metinlerinde de, o iletişim durumlarına uygun olan karakterler başkarakter olarak konumlandırılmaktadır. Farklı özellikler taşıyan karakter zenginliği, ders kitabı yazarlarına konuya uygun diyalog yazımında kolaylık sağlamaktadır.

A1 ve A2 düzeyinde, sadece belirli bir karakterin başından geçenler anlatılmamakta, birden çok karakter farklı dilsel bağlamlarda iletişime geçmektedir. Bu, önceden okunan metinle yeni okunan metin arasında ilişki kurma becerisini artırabileceği gibi, daha sonra okunacak metinlere yönelik de beklenti oluşturması bakımından dikkat çekicidir. Örneğin A2 düzeyindeki kitabın ikinci ünitesinde Murat ve Zeynep arasında sağlık üzerine bir konuşma yer alırken dördüncü ünitede Murat ve Yaren arasında yöresel lezzetler üzerine bir konuşma geçmektedir. Beşinci ünitede de Zeynep ve Canan'ın alışverişi diyalog hâlinde verilmiştir. Görüldüğü gibi diyaloglarda karakterler tekdüze bir sıra izlememekte, değişik dilsel bağlamların yer aldığı diyalog metinlerinde farklı karakterler ara ara yer almaktadır. Böylece sadece bir veya sınırlı sayıdaki karakterin yer aldığı metinlerin okuru sıkmasını önlemek amaçlanmakta, bununla beraber hep farklı karakterlerdense belirli karakterlerle okuyucunun var olan bilgileri, yeni becerilerin kazandırıması için öğretime zemin hazırlamaktadır. İncelenen kitaplardaki karakter aşamalıı̆̆ının, öğrencilerin ön organize edicilerini kullanarak yeni beceriler kazanmalarına olanak sağlayabileceği düşünülmektedir.

Diyalog metinlerinde temalar arasında karakterler aşama aşama yapılandırıldığı gibi A1 ve A2 düzeyindeki kitaplar arasında da ortak karakterler yer almaktadır. Sözgelimi A1 düzeyindeki kitabın yedinci ünitesinde Filiz Hanım'ın uçak bileti almak için sekreterle girdiği diyalog yer almaktadır. A2 düzeyindeki kitabın altıncı ünitesinde Filiz Hanım, kızı Esra ile yeni gelen komşuları hakkında konuşmaktadır. A1 düzeyinde yer alan diğer birçok karakter de A2 düzeyindeki kitapta, farklı bağlamlarda diyalog metinlerinde yer almaktadır. Bu durum, düzeyler arasındaki kopukluğun giderilmesi bakımından önem taşımaktadır. Kısacası bu ders kitaplarındaki metinler arası karakter aşamalılığı, öğrencilerin öncel metinlerle ilişki kurmalarına, sonraki metinlere hazırlanmalarına olanak sağlayacak niteliktedir.

\section{4. İzmir'de Metinler Arası Karakter Aşamalıılı̆ığına İlişkin Bulgular ve Yorum}

Yedi İklim Türkçe ile İzmir ders kitapları, metinler arası karakter aşamalılığı bağlamında açık bir biçimde farklılaşmaktadır. İzmir'in hem A1 hem de A2 düzeyindeki kitaplarında karakter aşamalııı̆ının zayıf olduğu belirtilmelidir. İzmir'de gerek diyalog metinlerinde gerekse diğer metinlerde karakterler yer almakta; fakat bu metinlerde birbiriyle bağlantısı olmayan farklı karakterler kullanılmaktadır. İzmir'deki karakterler her metinde farklılaşmakta, öğrenci sürekli yeni karakterlerle tanışmaktadır. Bu durum, metni okurken ilişkilendirmeyi, devamlılı̆ı ve aşamalııı̆ı olumsuz yönde etkileyebilir. Dilsel bağlamlara uygun karakter zenginliği, ders kitabı yazarına metni oluştururken; öğrenciye de metni anlamlandııırken kolaylık sağlayabilir.

İzmir Yabancılar İçin Türkçe ders kitabı hazırlanırken tema içi, temalar arası ve kitaplar arası karakter aşamalııı̆ı gözetilmemiştir. Karakter aşamalılığı bakımından Yedi İklim Türkçe, İzmir'le karşılaştırıldığında; Yedi İklim Türkçe ön plana çıkmaktadır.

\subsection{Yedi Iklim Türkçe'de Metinler Arası Fotoğraf Aşamalıı̆̆ına ilişkin Bulgular ve} Yorum

Kendi içinde bir bütünlük ve tutarlılık taşıdığı için fotoğraflar da metin olarak kabul edilmektedir. İncelenen ders kitaplarında yer alan fotoğraflarda, metinler arası aşamalılık belirgindir. Metni anlamlandırmayı sağlayan bu fotoğraflar, ders kitaplarındaki metinleri yansıtmayı amaçlamaktadır. Bu yüzden fotoğraflardaki karakterler birbiriyle ya akrabalık ya da arkadaşıı ilişkisi içindedir. Olaya dayalı bu metinlerde karakterler arasındaki iletişim, 
fotoğraflarla desteklenmektedir. Dolayısıyla metinlere ve metinlerde yer alan karaktere koşut olarak fotoğraflar da birbirinin üstüne yapılandırılan bir aşama izlemektedir.

Ünite içinde olduğu gibi, üniteler arasında hatta A1 ve A2 kitapları arasında da fotoğraflar arası aşamalıık göze çarpmaktadır. Yani A1 kitabındaki ilk ünitenin içinde birbirini sürükleyen fotoğraflar olabildiği gibi, A1 kitabının birinci ve ikinci üniteleri arasında da ilişkilendirme gerektiren fotoğraflar bulunabilmekte ve hatta $A 1$ ve $A 2$ kitaplarında da devamlılı̆ı sağlayan fotoğraflara rastlanabilmektedir. Sözgelimi A1 kitabında ikinci ünitede "Kaç Kardeşin Var?" başıklı metinde Yaren ile Derya'nın fotoğrafı yer almaktadır. Yine Aynı tema içinde şimdiki zamanın öğretiminde dokuzuncu ve on birinci etkinliklerde Yaren'in fotoğrafı dikkat çekmektedir.

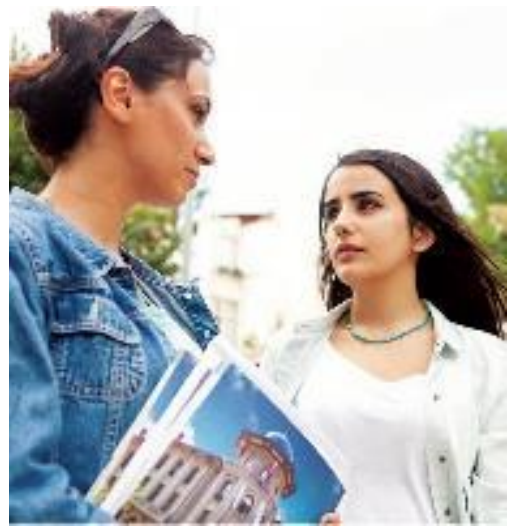

Fotoğraf 1: Kaç kardeşin var?

Yaren ağlıyor mu?

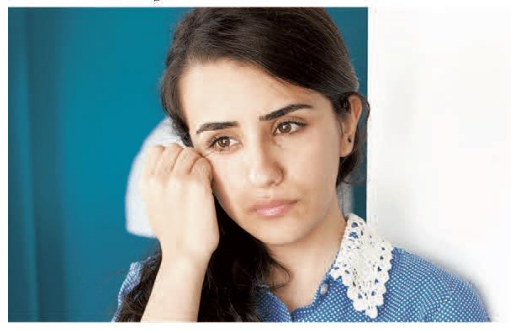

Evet, Yaren ağlıyor.

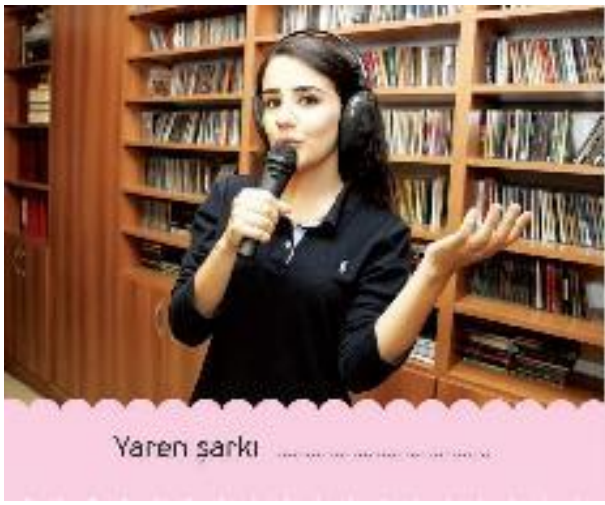

Fotoğraf 2: Ne yapıyor?

Fotoğraf 3: Yaren ağlıyor mu?

A1 kitabının üçüncü ünitesinde "Bilet Var mı?" başlıklı metinde Murat'ın fotoğrafı kullanıırken aynı kitabın yedinci ünitesindeki "Cep Telefonu Alıyoruz" başlıklı metin için de diyaloglara uygun olarak Murat'ın fotoğrafı kullanılmıştır.
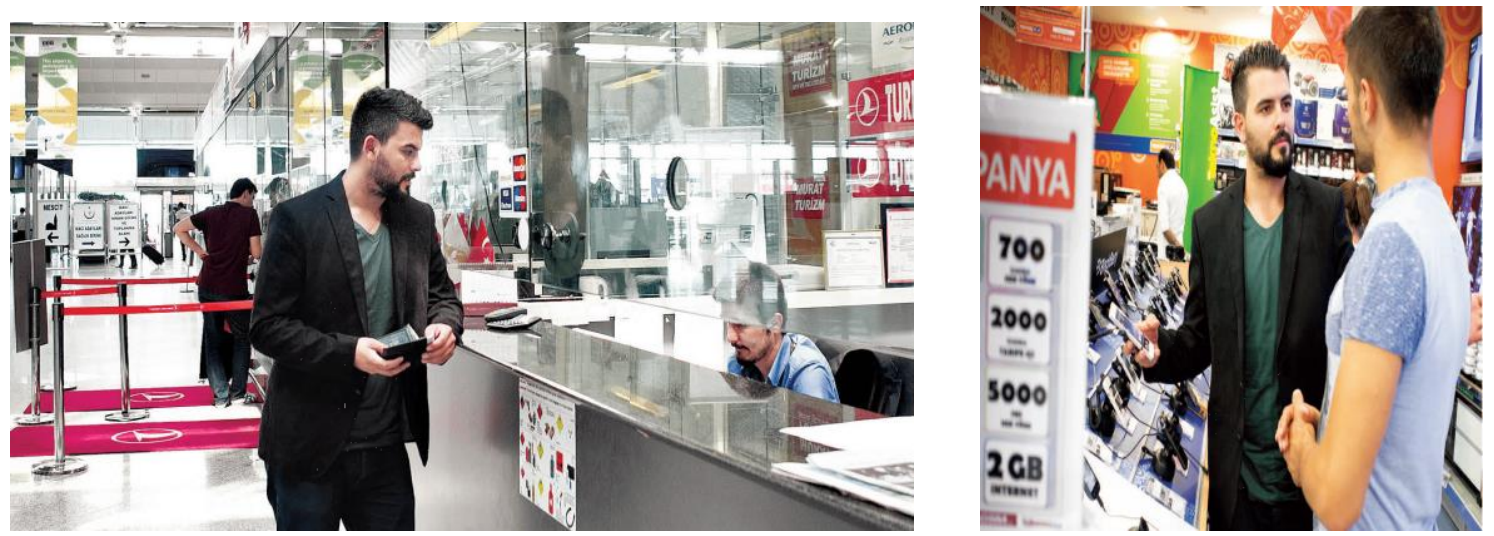
Tema içi ve temalar arası fotoğraf aşamalıılı̆ı olabildiği gibi, kitaplar arası araşamalıık da dikkat çekmektedir. Sözgelimi A1 kitabında ikinci ünitede "Maç Başlıyor" başlıklı metinde Kemal ve Sedat'ın fotoğrafı kullanılmıştır. A2 kitabının yedinci ünitesinde "Hafta Sonu Ziyareti" başlıklı metinde Kemal Bey ve ailesinin fotoğrafı yer almıştır.

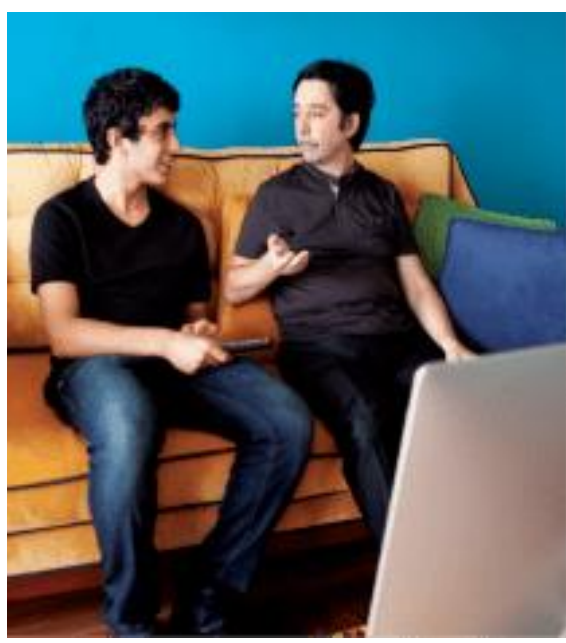

Fotoğraf 6: Maç başlıyor

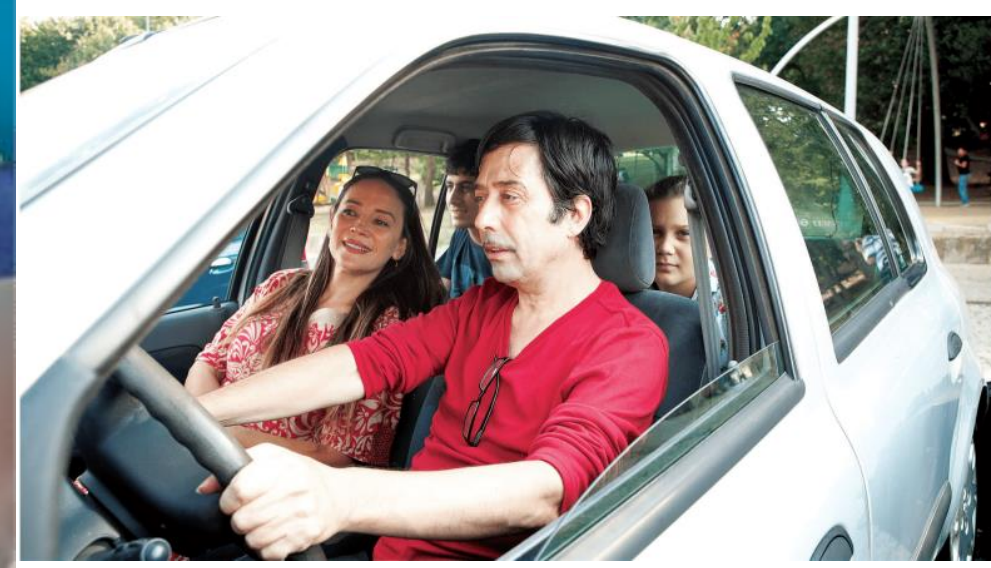

Fotoğraf 7: Hafta sonu ziyareti

Metne dayalı fotoğraflar olmakla beraber aynı zamanda dilbilgisel yapıların öğretiminde de öğrencinin daha önce tanıştığı karakterlerin fotoğrafları kullanılmaktadır. Sözgelimi A1 düzeyinde şimdiki zaman çekimi veya "ile"nin kullanımı öğretilirken daha öncekilerle bağlantılı fotoğraflara yer verilmiştir.

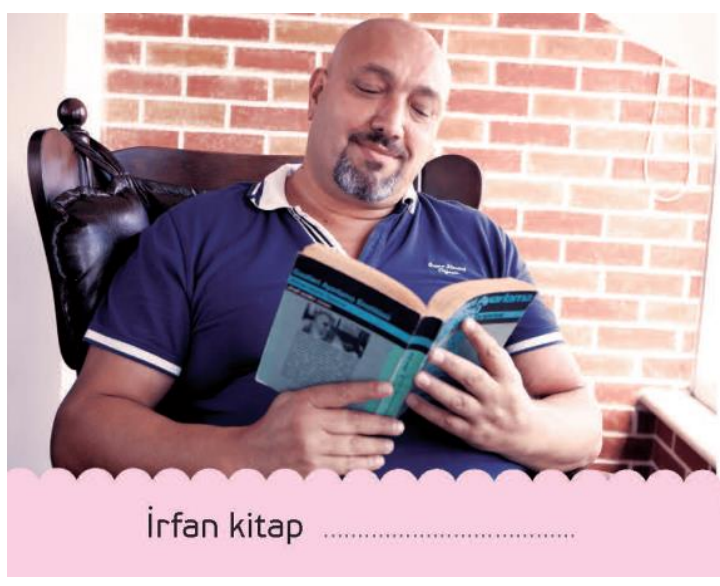

Fotoğraf 8: Ne yapıyor?

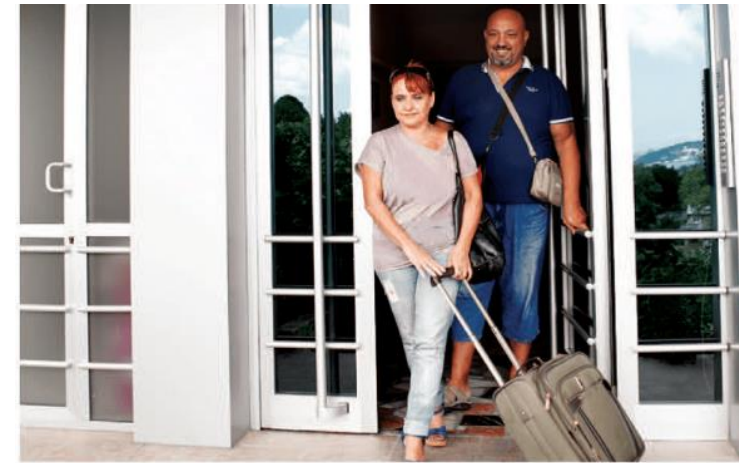

Annem

\section{babam tatile çıktı.}

Fotoğraf 9: Annemle babam...

Kimi zaman, karakterlerin konuşmalarında geçen bir olay veya durum, ilerleyen sayfalarda karakterden bağımsız bir biçimde fotoğraf olarak yer alabilmektedir. Sözgelimi A2 düzeyinde 4. temada "Yöresel Tatlılar Festivali"nin ele alındığı bir diyalog metninde iki karakter 
fotoğrafı yer almaktadır. Aynı tema içinde daha sonra ise "Afiyet Olsun" başlıklı dinleme metninde yine yöresel tatılırın fotoğrafları kullanılmıştır. Aynı tema içinde "Sütlü Tatılıar" başlıklı okuma metninde sütlaç ve keşkülün tarifi verilmiş, sütlacın fotoğrafı yer almıştır. Tema sonundaki serbest okuma metninde ise hem güllacın hem de aşurenin fotoğrafına yer verilmiştir. Görüldüğü gibi tema içindeki konu sürekliliği, fotoğraflarla da desteklenmiş ve fotoğraflar yardımıyla aşamalı ilerleme sergilenmiştir.

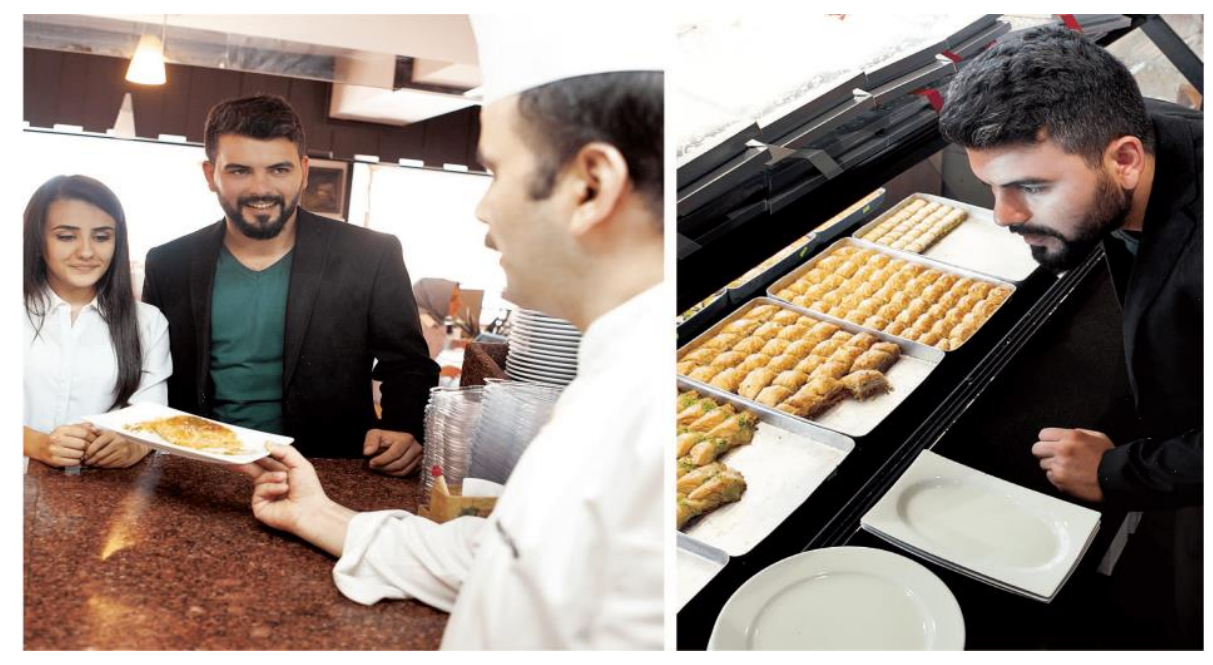

Fotoğraf 10: Festivale gidiyoruz
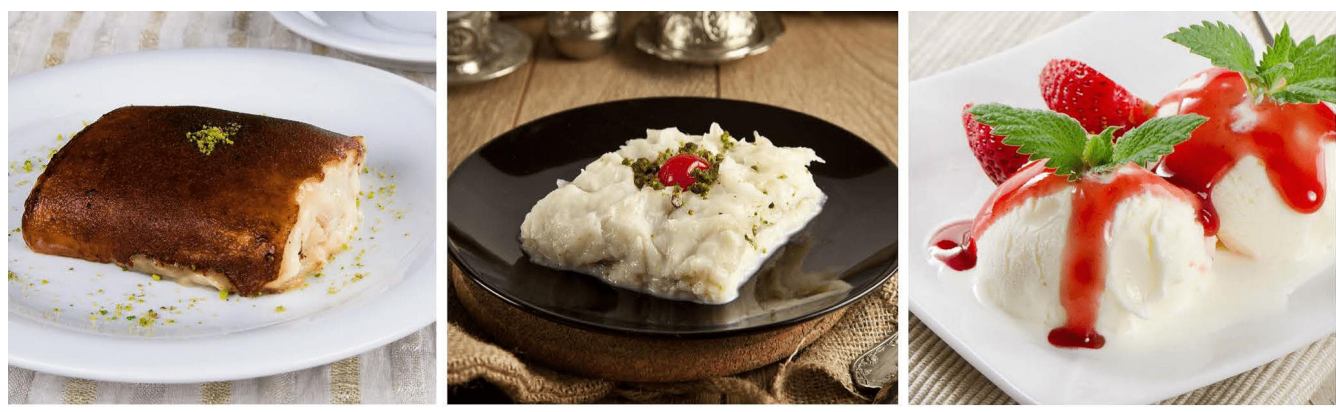

Fotoğraf 11: Afiyet olsun

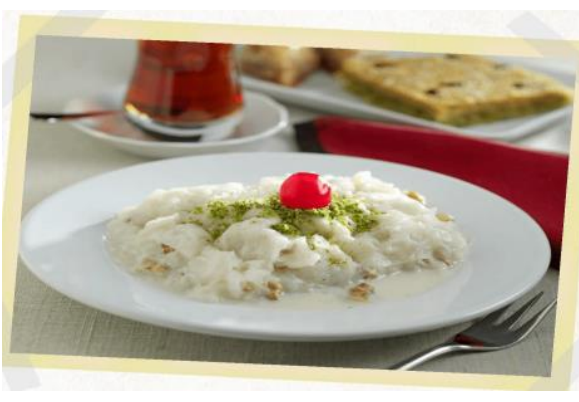

Fotoğraf 12: Güllaç

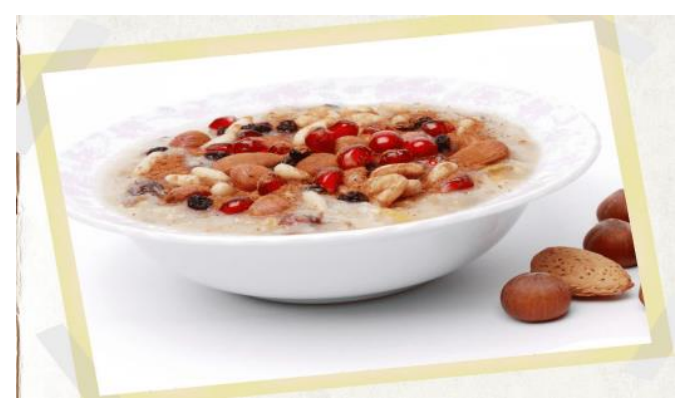

Fotoğraf 13: Aşure

Yedi İklim Türkçe'deki metinler arası fotoğraf aşamalılığı, öğrencinin parçadan bütüne gitme ve ilişkilendirme becerisine katkı sunabilecek niteliktedir. 


\section{6. İzmir'de Metinler Arası Fotoğraf Aşamalılığına ilişskin Bulgular ve Yorum}

Yedi İklim Türkçe ile İzmir'in farklılaştığı bir diğer nokta da metinler arası fotoğraf aşamalııı̆ıdır. İzmir Yabancılar İçin Türkçe A1 ve A2 ders kitaplarında fotoğraf bulunmamaktadır. Kitaplardaki metinler ve etkinlikler, fotoğraf yerine görsellerle desteklenmiştir.

İzmir Yabancılar İçin Türkçe'de metinler arası fotoğraf aşamalılı̆̆ı yoktur. Bu durum, öğrencinin fotoğraf aracılığıyla dil becerisini desteklemesini, fotoğraflar arasında ilişki kurmasını zayıflatmaktadır.

\section{SONUÇ, TARTIŞMA VE ÖNERILER}

Yunus Emre Enstitüsünün hazırladığı Türkçenin yabancı dil olarak öğretiminde kullanılan Yedi İklim Türkçe ile Dokuz Eylül Üniversitesi DEDAM'ın hazırladığı İzmir ders kitaplarında yer alan metinlerin, metinler arası aşamalılı̆ını betimlemeyi amaçlayan bu çalışmada ulaşılan sonuçlar aşağıdaki gibi sıralanabilir:

- Genel olarak Yedi İklim Türkçe'nin İzmir'e göre metinler arası aşamalılığa daha uygun olarak örgülendiği tespit edilmiştir.

- Yedi İklim Türkçe'deki metinler, ünite içi metinler arası konu aşamalılığı gözetilerek hazırlanmıştır.

- Yedi İklim Türkçe'de üniteler arasındaki konu aşamalılığı bakımından A1 kitabı, A2'ye göre daha ilişkisel ve tutarlı bir sıradüzen izlemektedir. Bu sıradüzen, Türkçeyi yabancı dil olarak öğrenen öğrencilerin dil becerilerini yapılandırmalarına, dilsel davranışlarını inşa etmelerine olanak sağlayabilir.

- İzmir'in Yedi İklim Türkçe'ye göre üniteler arası konu aşamalııı̆ı bakımından daha az bağlantılı olduğu söylenebilir. Yedi İklim'in A1 kitabında üniteler arasında bir sıradüzen ilişkisi varken İzmir'in hem A1 hem de A2 kitabında ünitelerin birbiriyle bağlantısı daha zayıftır. Bu durum, bir üniteden diğerine geçerken kopukluğa ve dağınıklığa yol açabilir.

- İzmir'in A2 kitabının A1'e göre ünite içi metinler arası konu aşamalılı̆ı bakımından daha tutarlı olduğu söylenebilir.

- Yedi İklim Türkçe'de diyalog metinleri oluşturulurken, okuyucunun zaman zaman tekrar karşısına çıkan farklı karakterlerden yararlanılmıştır. Karakterlerin diyaloglara dağıımı, tekdüze bir sıra izlememektedir. Bu karakterler, iletişim bağlamına göre farklı diyaloglarda merkezî bir rol üstlenmektedir.

- Yedi İklim Türkçe'de A1 kitabında yer alan birçok karakter, A2 kitabında da okuyucunun karşısına çıkmaktadır. Bu durum, düzeyler arasındaki kopukluğun giderilmesi bakımından önem taşımaktadır.

- Yedi İklim Türkçe'deki karakter aşamalılığı, öğrencilerin ön organize edicilerini kullanarak yeni beceriler kazanmalarına zemin hazırlayabilir.

- Farklı özellikler taşıyan karakter zenginliği, ders kitabı yazarlarına konuya uygun diyalog yazımında kolaylık sağlamaktadır.

- İzmir Yabancılar İçin Türkçe ders kitabı hazırlanırken tema içi, temalar arası ve kitaplar arası karakter aşamalılı̆ı gözetilmemiştir. Yedi İklim Türkçe, İzmirle karşılaştırıldığı karakter aşamalıı̆̆ı bakımından ön plana çıkmaktadır.

- Yedi İklim Türkçe'de metinler arası karakter aşamalılığına koşut olarak fotoğraf aşamalııl̆̆ da öğrencilerin öncel metinlerle ilişki kurmasını, sonraki metinlere hazırlanmasını sağlayacak niteliktedir.

- Yedi İklim Türkçe'de Tema içinde fotoğraflar arası aşamalılık olduğu gibi, temalar arasında, hatta A1 ve A2 kitapları arasında da fotoğraflar arası aşamalılık göze çarpmaktadır. 
- İzmir Yabancılar İçin Türkçe A1 ve A2 ders kitaplarında fotoğraflar yer almamaktadır. Bunun yerine kitaplarda metinler ve etkinlikler görsellerle desteklenmiştir. Bu nedenle İzmir, metinler arası fotoğraf aşamalılığı bakımından değerlendirilememiştir.

- Yedi İklim Türkçe'de, dilbilgisi yapıları metne dayalı olarak verilmiştir. Bu durum, bir metinler arasılık ilişkisi olarak değerlendirilebilir.

Ulaşılan sonuçlar, metinler arası aşamalııık bağlamında incelenen ders kitaplarının farklılıklar gösterdiğini ortaya koymaktadır. Bu sonuçlardan hareketle aşağıdaki öneriler ileri sürülebilir:

- Son yıllarda hızla gelişen yabancı dil olarak Türkçe öğretimi alanında hazırlanacak ders kitaplarında metinler arası aşamalııık ilkesi gözetilmelidir.

- Ders kitaplarındaki metinler arası aşamalııı̆ın, yabancı dil olarak Türkçe öğretimindeki etkisinin sınandığı deneysel çalışmalar yapılabilir.

- Yedi İklim Türkçe ile İzmir'in yanı sıra uygulamada sıkça kullanılan Gazi Üniversitesi, İstanbul Üniversitesi ve Yeni Hitit Türkçe setleri de metinler arası aşamalııı açısından incelenebilir ve karşılaştırılabilir.

- Yabancı dil olarak İngilizce, Almanca ve Fransızca önemli bir akademik geçmişe ve birikime sahiptir. Bu nedenle bu dillere ait ders kitaplarıyla Türkçe ders kitapları, metinler arası aşamalılık bağlamında karşılaştırılabilir.

- Bu çalışmada metinler arasılık, öğretimsel aşamalılık ilkesi bağlamında ele alınmıştır. Söz konusu metinler alıntı, anıştırma, öykünme, parodi, alaycı dönüştürüm gibi metinler arasılık tarzlarına göre de incelenebilir.

- Türkçeyi yabancı dil olarak öğrenenlerin yazılı ve sözlü metinlerindeki metinler arası ilişkilerin betimlendiği çalışmalar yapılabilir. Ulaşılan sonuçlar, ders kitaplarındaki metinler arası ilişkilerle karşılaştırılabilir.

\section{KAYNAKLAR}

Aktulum, K. (2014). Metinlerarası ilişkiler. Ankara: Kanguru Yayınları.

Alforo, M. J. M. (1996). Intertextuality: origins and development of the concept. Atlantis, 17 (12), 268-285.

Allen, G. (2005). Intertextuality. London and Newyork: Routledge Taylor \& Francis Group.

Ayata Şenöz, C. (2005). Metindilbilim ve Türkçe. İstanbul: Multilingual.

Bauman, R. (2008). Tür, performans ve metinlerarasılığın üretimi. (I. Altun, çev.), Milli Folklor, 20 (78), 114-122.

Biçer, N. ve Çoban i. (2015). Yabancılara Türkçe öğretimi ders kitaplarındaki öyküleyici metinlerin tutarlılık düzeylerinin değerlendirilmesi. Eğitim ve Öğretim Araştırmaları Dergisi, 4 (4), 228-237.

Bloome, D. ve Egan-Robertson, A. (1993). The social construction of intertextuality in classroom reading and writing lessons. Reading Research Quarterly, 28 (4), 304-333.

Can, R. (2014). Ortaöğretim öğrencilerinin bağdaşıkıı araçlarını işlevlerine göre yazılı anlatımlarında kullanma becerileri. Erzincan Üniversitesi Eğitim Fakültesi Dergisi, 16 (2), 204-228.

Coşkun Ögeyik, M. (2008). Metinlerarasılık ve yazın eğitimi. Ankara: Anı.

Çeçen, M. A. ve Doğan, B. (2014). Türkçe ders kitaplarında yer alan okuma kültürü teması metinlerinin metinler arasılık bakımından incelenmesi. Ana Dili Eğitimi Dergisi, 2 (3), 122-134. 
Çocuk, H. E. ve Kanatlı, F. (2012). Yazılı anlatım ürünlerinde Türkçe eğitimi lisans öğrencilerinin metinsellik ölçütlerini kullanabilme durumları: Mersin Üniversitesi örneği. 5. Uluslar arası Türkçenin Eğitimi Öğretimi Kurultayı, 67-76.

De Beaugrande, R. A. Ve Dressler, W. U. (1981). Introduction to text linguistic. London: Langman Group Company.

Demir, T. (2006).Peyami Safa'nın "Yalnızız" adlı romanının metindilbilimsel çözümlemesi. (Yayımlanmamış Yüksek Lisans Tezi). Kafkas Üniversitesi Sosyal Bilimler Enstitüsü, Kars.

Demir, T. (2009). Türkçe öğretiminde metinlerarasılık. IV. Sosyal Bilimler Eğitimi Kongresi. Marmara Üniversitesi, 7-9 Ekim 2009, İstanbul.

Ekiz, T. (2007). Alımlama estetiği mi metinlerarasılık mı?. Ankara Üniversitesi Dil ve TarihCoğrafya Fakültesi Dergisi, 47 (2), 119-127.

Eziler Kıran, A. ve Kıran, Z. (2011). Yazınsal okuma süreçleri. Ankara: Seçkin.

Göçer, A. (2012). Türkçe öğretmen adaylarının yetizleme çalışmalarıyla oluşturdukları metinlerin metinlerarasılık: dilsel metinlerin kullanımı açısından incelenmesi. International Online Journal of Educational Sciences, 4 (1), 184-195.

Günay, D. (2007). Metin bilgisi. İstanbul: Multilingual.

Kanatlı, F. (1998). Dilbilimsel gerekçelendirme çözümlemesi -Almanca ve Türkçe boşanma metinleri bağlamında gerekçelendirme ve belirleyenleri-. (Yayımlanmamış Doktora Tezi). Çukurova Üniversitesi Sosyal Bilimler Enstitüsü, Adana.

Karaağaç, G. (2013). Dil bilimi terimleri sözlüğü. Ankara: TDK.

Karadeniz, A. (2015). Metin dilbilimi temelli metin çözümlemesinin bağdaşıklık araçlarını kullanma ve tutarlı metin oluşturma becerisine etkisi. Mersin Üniversitesi Eğitim Fakültesi Dergisi, 11 (1), 1-17.

Karatay, H. (2010a). Bağdaşıklık araçlarını kullanma düzeyi ile tutarlı metin yazma arasındaki ilişki. Mustafa Kemal Üniversitesi Sosyal Bilimler Enstitüsü Dergisi, 13 (7), 373-385.

Karatay, H. (2010b). Türkçe dersi öğretim araçlarında yapılandırmacılık: metinlerarasılık. Mustafa Kemal Üniversitesi Sosyal Bilimler Enstitüsü Dergisi, 7 (14), 155-178.

Karatay, H. (2013). Okuma eğitimi: kuram, uygulama, ölçme ve değerlendirme. A. Güzel ve H. Karatay (Ed.), Türkçe öğretimi el kitabı içinde, (s. 221-264).Ankara: Pegem Akademi.

Kartal, H. ve Bozkurt, M. (2014). Okuma-yazma öğreniyorum ders kitabında yer alan metinlerin bağlaşık ve bağdaşıklık yönünden incelenmesi. Adıyaman Üniversitesi Sosyal Bilimler Enstitüsü Dergisi, 7 (18), 629-655.

Korkut, E. (2015). Metin dilbilimi ve dil öğretimi. E. Korkut ve i. Onursal Ayırır (Ed.), Dil bilimleri ve dil öğretimi içinde (s. 159-188). Ankara: Seçkin.

Kristeva, J. (1969). Semeiotike recherces pour une semanalyse. Paris: Seuil.

Sakalı, C. (2014). Karşılaştırmalı yazınbilim ve yazınlararasılık/sanatlararasılık üzerine. Ankara: Seçkin.

Seçkin, P., Arslan, N. ve Ergenç, S. (2014). Bağdaşıklık ve tutarlılık bakımından lise ve üniversite öğrencilerinin yazılı anlatım becerileri. Uluslar arası Türkçe Edebiyat Kültür ve Eğitim Dergisi, 3 (1), 340-353. 
Still, J. ve Worton, M. (1990). Introduction. M. Wortand ve J. Still (Ed.), Intertextuality theories and practices içinde (s. 2-44). Manchester and New York: Manchester University Press.

Taşıgüzel, S. (2004). İlköğretim Türkçe ders kitaplarında öğretici nitelikteki metinlerdeki eşdizimsel örüntülemelerin görünümü. Ankara Üniversitesi Dil Dergisi, 125, 72-87.

Ülper, H. (2011). Öğrenci metinlerinin tutarlılık ölçütleri bağlamında değerlendirilmesi. Turkish Studies, 6 (4), 849-863.

Yıldırım, A. ve Şimşek, H. (2008). Sosyal bilimlerde nitel araştırma yöntemleri. Ankara: Seçkin Yayınevi. 


\section{SUMMARY}

The aim of this research is to try to describe the intertextual progressivity of texts in Yedi İlim Türkçe (Yunus Emre Institue) and İzmir (Dokuz Eylül University DEDAM) textbooks. For this purpose, textbooks at the A1 and A2 level have been examined comparatively. Intertextual progressivvity is at the center of this work. Intertextual progressivity is a matter of intertextuality, a method of text linguistics.

Text linguistics deals with writing, receptioning and evaluating of text. Reference relations are the main occupation of text linguistics. In other words, text linguistics is one of the subfields of linguistics that investigate relationships between text types, and attempt to determine the meaningless structures and the communicative functions of texts. Textuality measures are one of the most important issues in this area. At this pont, intertextuality is one of the seven textuality criteria in the literature.

Intertextuality is a interdisciplinary concept, which is the subject and method of examination of many different disciplines, from literature to folklore, from linguistics to media studies. The intertextuality are like mutual barber mirrors or a house with endless rooms, opening its each door to another room. Each text is naturally associated with another text. The reader traces another text in every text and this journey is endless. Therefore, intertextuality means visiting different texts and going on an endless journey. In other words, intertextuality is the cooperation of different texts. From this point of view, the texts are not point-wise but procedural, not linear, but zigzag, so both the author and the reader try to construct meaning on this zigzagged path. According to intertextuality, the reader is not the passive receiver of the text, but the meaning partner of the text. In this respect, the existence of intertextual relations in texts in textbooks can contribute to the analysis, association, justification and combining skills. In short, intertextuality is a criterion of textuality which, besides being a writing and reading technique, positively contributes to the process of constructing meaning and organizating knowledge in lessons.

The above explanations show that the nature of text is intertextual. That's why texts in textbooks should be organized systematically, not randomly. Turkish textbooks are not a randomly stacked text repository. The texts in these books must follow each other and contain each other. At the same time, teaching Turkish as a foreign language is based on text reception and text production. Teherefore, it is a necessity to do text linguistic studies and intertextual relations in the field of teaching Turkish as a foreign language. In the study, the intertextual progressivty in the Seven Climate Turkish and İzmir textbooks has been examined comparatively under three different headings:

1. Intertextual Subject Progressivity

2. Intertextual Character Progressivity

3. Intertextual Photo Progressivity

In this study which has a descriptive nature, document analysis method is used. Intertextual progressivity have been evaluated comparatively in three sub-sections: topic, character and photo progression. In the research, it was determined that Yedi İlim Türkçe is more appropriately organized in terms of intertextuality progressivity according to İzmir. As a result, intertextual progressivty in Turkish teaching textbooks as a foreign language should be considered. 